\title{
The cruciate question: what are the right questions to ask when evaluating clinical outcomes from cruciate ligament surgery in the dog?
}

Paul RM*

MRCVS, Astonlee Veterinary Hospital, Newport Pagnell, UK

\begin{abstract}
Objective: To meet the challenge of producing a clinical outcome measure, with wide application and acceptance in both clinical practice and academia for evaluating cruciate surgery in the dog.

Background: Cruciate surgery in the dog has gone through a number of changes over the years since 1952 when Paatsama published his original MSc thesis in Finland describing the use of bone tunnels and a fascia graft for replacing the ruptured cranial cruciate ligament.
\end{abstract}

\section{Summery}

The questions vets and clients ask are often different, but they all matter.

\section{Introduction}

The published peer reviewed evidence that explores comparison between the old skin graft technique and more modern osteotomy techniques is non-existent. There was never any real study of the old techniques and their advantages and disadvantages before the proposed change to osteotomy techniques first by Barclay Slocum in 1994 was accepted, and there still is none in spite of wide acceptance of these new and much more radical techniques [1] compared the TPLO to the lateral suture technique [2]. Did some radiographic comparisons of outcomes between TPLO and lateral suture. However, in human surgery replacement graft techniques have been and still are used all around the world, and a large amount of research has been done into this including evaluation of outcomes and the development of national knee registries [3-6] (Table 1) (Figure 1).

The goal of advancement in surgery should be to improve the outcomes, so the development of a description of what a successful outcome looks like is critically important.

Table 1. Cruciate surgery in the dog has gone through a number of changes over the years since 1952 when Paatsama published his original MSc thesis in Finland describing the use of bone tunnels and a fascia graft for replacing the ruptured cranial cruciate ligament.

\begin{tabular}{|l|l|l|}
\hline Date & Research & Evidence based reason \\
\hline $\begin{array}{l}\text { 1952 Paatsama (41) } \\
\text { 1963 Vaughan (54,55) }\end{array}$ & $\begin{array}{l}\text { MSc thesis Helsinki. } \\
\text { JSAP article presenting } \\
\text { clinical case series }\end{array}$ & $\begin{array}{l}\text { Original research. Tissue } \\
\text { transplant. } \\
\text { Modified choice of natural } \\
\text { graft material with clinical } \\
\text { case evidence }\end{array}$ \\
\hline 1970 & $\begin{array}{l}\text { Lateral suture } \\
\text { OTT (over the top) }\end{array}$ & $\begin{array}{l}\text { DeAngelis \& Lau } \\
\text { Looking at simplifying the } \\
\text { technique }\end{array}$ \\
\hline 1994 Barclay Slocum & $\begin{array}{l}\text { Theoretical. } \\
\text { Metal implant. }\end{array}$ & $\begin{array}{l}\text { Originally theory was } \\
\text { presented in a non-peer } \\
\text { reviewed journal with no } \\
\text { clinical case evidence }\end{array}$ \\
\hline
\end{tabular}

\section{Evidentiary value}

In veterinary surgery as compared to veterinary medicine, it is far more difficult to obtain large sample sizes for studies of surgical interventions compared to pharmaceutical interventions for example.

This study is limited by the number of responses to the survey in the Veterinary Times who were interested to complete the questionnaires. The Veterinary Times circulation was 20,000 readers, but only 250 responses were received. However, this may have been a reflection of the degree of interest in the subject matter, as well as the accepted low response rate to any questionnaire where $10 \%$ is considered excellent and good enough for Governments to make major decisions.

The clinical studies carried out by the author in his own practice had the advantage of long follow up times and the quite large number (100) of cases compared to the majority of papers published in the veterinary literature.

Whilst a much bigger number of cases and a bigger survey might be carried out in the future, it is hoped that this paper will provide the basis for further exploration of these important issues in the future, and improve the data gathering within the veterinary profession. The Scandinavian countries in particular, have developed National Joint Registries for their human knee patients which have a very high compliance rate above $80 \%$ for completing questionnaires by both surgeons and patients, and this is an aspiration of the author for the veterinary profession.

Correspondence to: Paul R. Manning, Astonlee Veterinary Hospital, Newport Pagnell, UK; E-mail: paulandhilary@clara.co.uk

Received: September 10, 2017; Accepted: October 06, 2017; Published: October 09,2017 


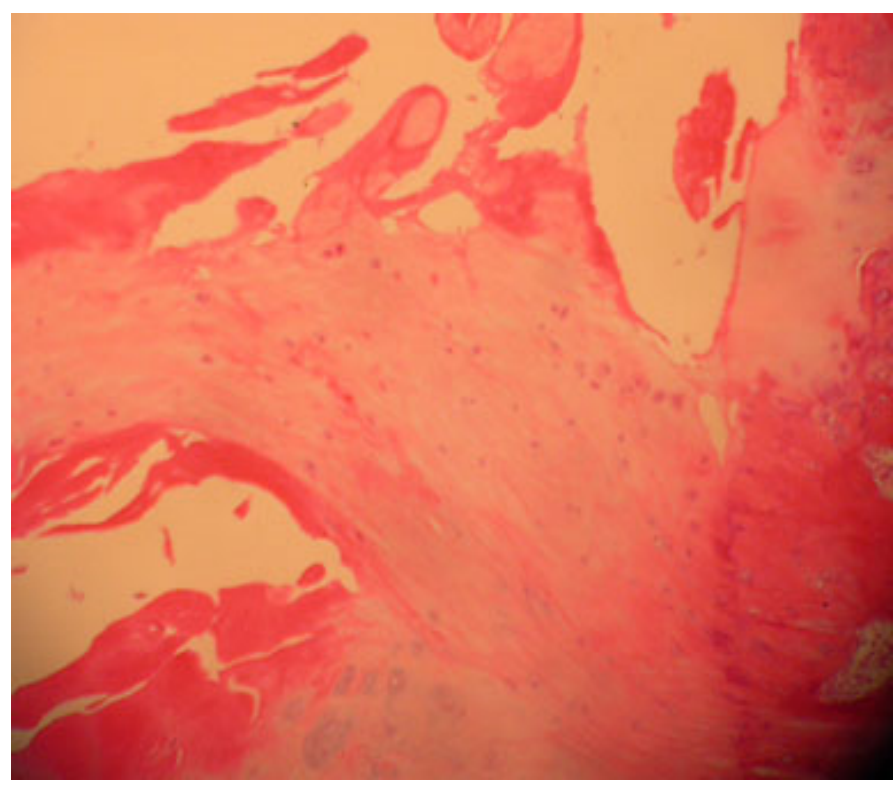

Figure 1. Picture of the graft in $\operatorname{dog} 8$ years after it was inserted. (Ligamentisation).

\section{Methods}

\section{Literature searches}

30 years of clinical experience of dealing with canine cruciate surgery: reflective practice. Clinical observation and analysis of more than 100 cases in a 15-year study [7]. Client feedback in the development of 'frequently asked questions' by clients over more than 20 years [8]. Survey of veterinary surgeon and veterinary nurse opinion of their view of the most important questions to ask circulated in a questionnaire with supporting articles in the Veterinary Times.

\section{Results}

Data has been collected using the above different methods.

\section{Conclusion}

Acceptability of a clinical outcome measure is likely to be based on the degree to which veterinary surgeons are willing to accept a challenge to their professional practice, and the academics' acceptance of the need to include the dog owners in the evaluation. 'We need to capture and share our legacy of raw data from surgery.'

This question is a valuable one to ask:

'Are there any things you have observed that your dog cannot do now he/she has recovered from the operation that he/she could do before the injury?'

Dog owner client feedback, observation and testimonial are vital keys on which the author's motivation works as a surgeon practitioner. Patient orientated evidence that matters (POEM's) should be important for vets now and in the future.

An airline pilot has to consider the evidence that helps to prevent a disaster happening when both the lives of his passengers and his/ her own life will be at stake from a failure to implement routines and procedures. A human surgeon has a human life at stake. A veterinary surgeon has his/her own reputation and that of the practice, plus the wellbeing of the patient and the real concerns of the client to take seriously.
The capture of data in this study has been done over three decades. The study shows that owner observation and feedback is an important part of the development and refining of a surgical technique which has resulted in a $96 \%$ success rate with very low complication rate. The findings have importance for future clinical decision making in cruciate surgery in the dog, and may have some value in developing an animal model for the equivalent surgery in humans.

\section{Application}

Practitioners and dog owning clients can share this data for the benefit of the dogs suffering from ruptured cruciate ligaments. Use in my own practice for my own clients and clients referred to me by other veterinary surgeons or clients who self-refer.

The concept of clinicians jointly evaluating the clinical outcomes of their services is something that has always been precious to me in my vocation, and I do not believe that I am alone in thinking this is important [9]. It would be unthinkable for clients or patients to think that their clinicians disregarded this.

In human medicine and surgery there is a long-held belief and practice that change needs to be evidence based, and carefully managed for the betterment of the service provided to patients. Radical changes may be beneficial but need to be justified with evidence. This has become institutionalised in the form of NICE (National Institute for Clinical Excellence) [10,11].

In veterinary surgery, there is very rarely any published evidence demonstrating a surgeon's complication rates to the public using those services, and if it is published in peer reviewed journals there is rarely any useful data to compare with other techniques.

'No one technique for cruciate surgery is proven to be any better than any other' continues to be stated in many standard textbooks in the absence of any data to prove otherwise. A recent textbook [12] devotes 10 pages to intra-articular grafts in dogs and concludes that it is curious why this is widely used in human surgery but not so much in dogs. There are no references to actual clinical data from this technique.

Examples of research already done in the veterinary profession include attempts to validate questionnaires for pain relief [2,13-15,1619], and research to explore perceptions of what veterinary surgeons and clients feel are important in evaluation of clinical outcomes [15,20-23].

Our medical colleagues have long used the IKDC [24,25] score to evaluate their clinical outcomes in cruciate surgery.

The force plate has held the position of gold standard for the belief in its objectivity [26].

Acceptability is likely to be based on the degree to which veterinary surgeons are willing to accept a challenge to their professional practice, as well as the academics' acceptance of the need to include the dog owners in the evaluation.

I believe the right question to ask is how can the veterinary profession better recognise the good work already done in qualitative analysis and be better trained in it?' [27-30]. The big question is 'how shall we share our raw data from surgery?'

\section{Literature searches}

There is no comparison in the peer reviewed published literature between osteotomy techniques and the old skin graft technique for cruciate surgery. 
There are some clinical outcome measures in the published literature, but none are widely used in practice except the simple lameness scores of 'not lame, slightly lame, moderately lame, severely lame.'

\section{Clinical cases by the author/surgeon [7].}

Lameness scoring (Ballagas, 2004). Table of outcomes from a case series of 100 dogs followed during a 15year study period (1988-2003) (Table 2).

\section{Breed codes:}

$\mathrm{R}=$ Rottweiller

$\mathrm{W} \& \mathrm{C}=$ West Highland White Terriers and Cairns.

SS= Springer Spaniel

$\mathrm{B}=$ Boxer

$\mathrm{BC}=$ Border Collie

$\mathrm{BMD}=$ Bernese Mountain Dog

$\mathrm{GD}=$ Great Dane

YT=Yorkshire Terrier

$\mathrm{X}=$ Cross breed

$\mathrm{L}=$ Labrador

$\mathrm{CS}=$ Cocker Spaniel

$\mathrm{MP}=$ Miniature Poodle

SBT=Staffordshire Bull Terrier

GSD $=$ German Shepherd Dog

$\mathrm{BF}=$ Bichon Freis

$\mathrm{TT}=$ Tibetan Terrier

JRT=Jack Russell Terrier

$\mathrm{BM}=$ Bull Mastiff

GS=German Spitz

$\mathrm{BD}=$ Bulldog

CKCS=Cavalier King Charles Spaniel

\section{$\mathrm{R}=$ Retriever}

BS=Belgian Shepherd

${ }^{\star}$ Became bilateral at end of the study.

One English Setter was removed from the study due to concurrent osteoarthritis of the hip. This case does not appear in the table (Table 3).

$58 \%$ of cases were followed for more than 2 years post operatively (Table 4).

Table 2. Lameness scoring (Ballagas, 2004).

\begin{tabular}{|c|l|}
\hline Lameness score & Interpretation \\
\hline 0 & Absent. \\
\hline 1 & $\begin{array}{l}\text { Minor gait abnormality with constant } \\
\text { weight bearing }\end{array}$ \\
\hline 2 & $\begin{array}{l}\text { Obvious gait abnormality with constant } \\
\text { weight bearing. }\end{array}$ \\
\hline 3 & Intermittent non-weight bearing. \\
\hline 4 & Non-weight bearing. \\
\hline
\end{tabular}

\section{Client feedback}

FAQ's on the www.astonlee.co.uk website. [7,8,31-33]

In 2010, this was a summary of the 10 most commonly asked questions by clients at Astonlee Veterinary Hospital:

Many clients who were considering the choices available to them for the remedy of their dog's lameness due to a ruptured cruciate ligament studied the questions posted on the practice website in detail. Asking these clients if they had all of their questions answered or in particular 'is there any one question that was not answered for you?' confirmed and added a few to the list of FAQ's collected together and published on www.astonlee.co.uk 25.11.16 (Table 5 and 6).

What are the treatment choices for my dog?

Why do you choose your skin graft technique?

What are the costs of each choice of procedure?

What is the potential for things to go wrong?

I have heard the meniscal cartilage can be a problem with some techniques?

I have heard a clunking noise when my dog walks lame. What is this?

If the operation does fail, what can be done about it?

Making the diagnosis: as you cannot see the ligament on an $\mathrm{x}$ ray, why are $\mathrm{x}$ rays taken?

Failure rates in humans and dogs with various types of cruciate surgery.

How quickly after the dog has suffered the cruciate ligament rupture should the surgery be done?

Will my dog have to be in a plaster cast, cage rested, and any other constraints during the recovery after the operation?

I have heard that grafts are not favoured by many vets in larger dogs because of a fear of failure of the graft, and that is why many vets recommend the TPLO or other bone sawing techniques?

Questionnaire published in the Veterinary Times (references to articles and questionnaire) [20,21].

The survey found answers to a detailed questionnaire about the opinions of veterinary surgeon and veterinary nurse readers asked the question 'what are the most important questions in evaluating outcomes from cruciate surgery in the dog?' This table is a summary of the questions that were considered to be the most important (Table 7).

There were other questions considered to be of less importance and these were also reported.

\section{Discussion}

Synthesis. Why? What? How? Has the paper answered your questions about the evaluation of clinical outcomes following cruciate ligament surgery?

Which stakeholders (patients, surgeons, clinics, professions) should have access to the raw data? Research embargoes do exist for various personal and commercial reasons, so is the care of the patient subservient to $3^{\text {rd }}$ party interests in the practice based research? What evidence would you consider to be pivotal to your thinking on this subject? 
Paul RM (2017) The cruciate question: what are the right questions to ask when evaluating clinical outcomes from cruciate ligament surgery in the dog?

Table 3. Breed and sex distribution. (Median $=$ where $n=2 r+1$, median $=$ the $(r+1)$ th observation. If $n$ is an even number $2 s$, median $=1 / 2$ way between the sth and $(s+1)$ th observations. If $\mathrm{s}$ and $(\mathrm{s}+1)$ are the same number, that is the median. Mean $=$ sample mean $=\mathrm{Ex} / \mathrm{n}$.)

\begin{tabular}{|c|c|c|c|c|c|c|c|c|c|c|c|c|}
\hline Breed & Nos & RH & LH & $\begin{array}{l}\text { Median Time to } \\
\text { Recover to 0 } \\
\text { lameness (Mean } \\
\text { in Brackets) }\end{array}$ & Nos failed & $\begin{array}{l}\text { Min time in } \\
\text { months }\end{array}$ & $\begin{array}{l}\text { Max Time In } \\
\text { months }\end{array}$ & Male & Female & Inc bilateral & $\begin{array}{c}\text { Median Follow } \\
\text { Up time (Mean } \\
\text { In Brackets) }\end{array}$ & $\begin{array}{l}\text { Range Of } \\
\text { Follow Up } \\
\text { times }\end{array}$ \\
\hline $\mathrm{R}$ & 9 & 5 & 4 & $6(6)$ & & 4 & 6 & 2 & 7 & 1 & $\begin{array}{l}2 \mathrm{yrs} \\
(2.1 \mathrm{y})\end{array}$ & $\begin{array}{l}0.75- \\
3 y r s\end{array}$ \\
\hline $\mathrm{W} \& \mathrm{C}$ & 4 & 3 & 1 & $3(3)$ & & 3 & 3 & 1 & 3 & 0 & $\begin{array}{c}3 \mathrm{yr} \\
(2.25 \mathrm{y})\end{array}$ & $\begin{array}{l}0.25- \\
3 \mathrm{yrs}\end{array}$ \\
\hline SS & 3 & 1 & 2 & $3(1.7)$ & & 1 & 3 & 2 & 1 & 0 & $\begin{array}{c}1 \mathrm{yr} \\
(1 \mathrm{yr})\end{array}$ & $1-1 \mathrm{yr}$ \\
\hline B & 8 & 3 & 5 & $3(3.6)$ & & 1 & 6 & 5 & 3 & 2 & $\begin{array}{c}3 \mathrm{yr} \\
(3.9 \mathrm{y})\end{array}$ & $2-7 y r s$ \\
\hline $\mathrm{BC}$ & 3 & 1 & 2 & $2(2)$ & & 1 & 3 & 1 & 2 & 1 & $\begin{array}{l}3 \mathrm{yrs} \\
(2.7 \mathrm{y})\end{array}$ & $2-3 y r s$ \\
\hline BMD & 1 & 0 & 1 & 3)3) & & 3 & 3 & 0 & 1 & 0 & $\begin{array}{l}5 \mathrm{yrs} \\
(5 \mathrm{yr})\end{array}$ & $5 y r s$ \\
\hline GD & $1 *$ & & & & & & & & & & & \\
\hline Breed & Nos & $\mathrm{RH}$ & LH & $\begin{array}{l}\text { Median Time } \\
\text { to Recover to } 0 \\
\text { lameness (Mean } \\
\text { in Brackets) }\end{array}$ & Nos failed & $\begin{array}{l}\text { Min time in } \\
\text { months }\end{array}$ & $\begin{array}{c}\text { Max Time In } \\
\text { months }\end{array}$ & Male & Female & Inc bilateral & $\begin{array}{c}\text { Median Follow } \\
\text { Up time (Mean In } \\
\text { Brackets) }\end{array}$ & $\begin{array}{l}\text { Range Of } \\
\text { Follow Up } \\
\text { times }\end{array}$ \\
\hline YT & 4 & 1 & 3 & $2(1.7)$ & 1 & 1 & 3 & 1 & 3 & 0 & $\begin{array}{c}0.5 \mathrm{y} \\
(0.56 \mathrm{y})\end{array}$ & $\begin{array}{c}2 \text { month } \\
-1 \mathrm{yr}\end{array}$ \\
\hline $\mathrm{x}$ & 28 & 13 & 15 & $2(2.5)$ & & 1 & 3 & 14 & 14 & 4 & $\begin{array}{c}3 y \\
(2.79 y)\end{array}$ & $\begin{array}{c}1 \text { month } \\
-7 \mathrm{yrs}\end{array}$ \\
\hline $\mathrm{L}$ & 7 & 4 & 3 & $2(2.4)$ & 1 & 1 & 3 & 5 & 2 & 2 & $\begin{array}{c}6 \mathrm{yrs} \\
(3.79 \mathrm{y})\end{array}$ & $\begin{array}{c}2 \text { months } \\
-8 y r s\end{array}$ \\
\hline CS & 2 & 2 & 0 & $2(2)$ & 1 & 1 & 3 & 1 & 1 & 0 & $\begin{array}{l}3.5 \mathrm{y} \\
(3.5 \mathrm{y})\end{array}$ & $3-4 y r s$ \\
\hline MP & 1 & 0 & 1 & failed & 1 & lame & lame & 1 & 0 & 0 & $2 \mathrm{y}(2 \mathrm{y})$ & $2 \mathrm{yrs}$ \\
\hline SBT & 3 & 1 & 2 & $3(3)$ & & 3 & 3 & 3 & 0 & 1 & $\begin{array}{c}2 y \\
(2.33 y)\end{array}$ & $1-3 y r$ \\
\hline GSD & 4 & 3 & 1 & $3(2.1)$ & & 0.5 & 3 & 1 & 3 & 0 & $4 y(3.3 y)$ & $1.5-5 y$ \\
\hline Breed & Nos & $\mathrm{RH}$ & LH & $\begin{array}{c}\text { Median Time } \\
\text { to Recover to 0 } \\
\text { lameness (Mean } \\
\text { in Brackets) }\end{array}$ & Nos failed & $\begin{array}{l}\text { Min time in } \\
\text { months }\end{array}$ & $\begin{array}{l}\text { Max Time In } \\
\text { months }\end{array}$ & Male & Female & Inc bilateral & $\begin{array}{c}\text { Median Follow } \\
\text { Up time (Mean In } \\
\text { Brackets) }\end{array}$ & $\begin{array}{l}\text { Range Of } \\
\text { Follow Up } \\
\text { times }\end{array}$ \\
\hline $\mathrm{BF}$ & 3 & 3 & 0 & $3(3)$ & & 3 & 3 & 0 & 3 & 0 & $\begin{array}{c}0.5 \mathrm{y} \\
(1.25 \mathrm{y})\end{array}$ & $\begin{array}{c}2 \text { month } \\
-3 y r s\end{array}$ \\
\hline TT & 2 & 1 & 1 & $2.5 \mid(2.5)$ & & 2 & 3 & 2 & 0 & 1 & $0.6 \mathrm{y}(0.6 \mathrm{y})$ & $\begin{array}{c}2 \text { months } \\
-1 \mathrm{yr}\end{array}$ \\
\hline JRT & 6 & 4 & 2 & $3(2.8)$ & & 2 & 3 & 1 & 5 & 0 & $2 \mathrm{y}(2.35 \mathrm{y})$ & $\begin{array}{c}1 \text { month } \\
-6 y r\end{array}$ \\
\hline $\mathrm{BM}$ & 2 & 2 & 0 & $2.5(2.5)$ & & 2 & 3 & 0 & 2 & 0 & $1 \mathrm{y}(1 \mathrm{yr})$ & $2 \mathrm{yrs}$ \\
\hline GS & 1 & 0 & 1 & $1(1)$ & & 1 & 1 & 0 & 1 & 0 & $3 y(3 y)$ & $3 y r s$ \\
\hline BD & 1 & 1 & 0 & $3(3)$ & & 3 & 3 & 1 & 0 & 0 & $8 \mathrm{y}(8 \mathrm{yr})$ & $8 \mathrm{yrs}$ \\
\hline CKCS & 2 & 1 & 1 & $3(3)$ & & 3 & 3 & 2 & 0 & 1 & $1 \mathrm{y}(1 \mathrm{y})$ & $1 \mathrm{yr}$ \\
\hline $\mathrm{R}$ & 4 & 2 & 2 & $3(3)$ & & 3 & 3 & 1 & 3 & 1 & $8 \mathrm{y}(6 \mathrm{yr})$ & $2-10 \mathrm{yrs}$ \\
\hline BS & 1 & 1 & 0 & $3(3)$ & & 3 & 3 & 1 & 0 & 0 & $3 y(3 y)$ & $3 y r s$ \\
\hline Total & 100 & 53 & 47 & $3(2.93)$ & 4 & 0.5 & 6 & 45 & 55 & 14 & $\begin{array}{c}3 \mathrm{yrs} \\
(2.84 \mathrm{y})\end{array}$ & $\begin{array}{l}\text { 1month } \\
-10 \mathrm{yrs}\end{array}$ \\
\hline
\end{tabular}

Table 4. Age distribution at time of operation. Median; Mean.

\begin{tabular}{|c|c|c|c|c|c|c|c|}
\hline Age at time of op & Nos of dogs & \begin{tabular}{|c|} 
Median time \\
to recover to 0 \\
lameness in months. \\
(Mean in brackets)
\end{tabular} & $\begin{array}{l}4 \text { cases did not } \\
\text { recover to zero } \\
\text { lameness }\end{array}$ & $\begin{array}{l}\text { Median Bodyweight } \\
\text { in kgs (Mean in } \\
\text { brackets) }\end{array}$ & $\begin{array}{l}\text { Median follow up } \\
\text { time in years. (Mean } \\
\text { in brackets). }\end{array}$ & $\begin{array}{c}\text { Range of follow up } \\
\text { time }\end{array}$ & Confidence interval \\
\hline$<$ lyear & 3 & $3(2.2)$ & & $20(17.3)$ & $3(2.75)$ & $0.25-5 y r s$ & \\
\hline $1-5 \mathrm{yrs}$ & 29 & $3(2.2)$ & $\begin{array}{c}1 \text { (severely obese) } \\
+1=2 \text { cases }\end{array}$ & $35(32.9)$ & $3(2.74)$ & $0.1-10$ years & \\
\hline $5-10 \mathrm{yrs}$ & 41 & $3(2.3)$ & 1 & $19(23.8)$ & $2.5(3.02)$ & $0.1-8 \mathrm{yrs}$ & \\
\hline $10-12$ yrs & 20 & $3(2.1)$ & & $15(17.2)$ & $3(2.72)$ & $0.2-7$ years & \\
\hline $12-14 \mathrm{yrs}$ & 7 & $2.5(2.6)$ & 1 & $16.5(14.3)$ & $1.75(2.0)$ & $0.5-3$ years & \\
\hline All dogs & 100 & $3(2.93)$ & 4 & $20(24.26)$ & $3(2.84)$ & $0.1-10 \mathrm{yrs}$ & \\
\hline Total & 100 & & & & & & \\
\hline
\end{tabular}


Table 5. Concerns of dog Owners

\begin{tabular}{|c|c|c|}
\hline Concern of dog owners & Astonlee solution & Evidence base \\
\hline Pain needing to be understood and treated & $\begin{array}{l}\text { First } 24 \mathrm{hrs} \text { after the op in hospital for pain relief and TLC, } \\
\text { thereafter routine pain relief at home. }\end{array}$ & $\begin{array}{l}\text { Case follow up with surgeon and client observation over } 30 \\
\text { years. Simple analgesic protocol at Astonlee. }\end{array}$ \\
\hline $\begin{array}{l}\text { Unable to enjoy exercise with the leg problem, but wanting to } \\
\text { walk, run and play again }\end{array}$ & $\begin{array}{l}\text { Restore joint stability and function with a new graft } \\
\text { replacement } \\
\text { Dogs encouraged to walk immediately after the op on a lead, } \\
\text { no need for cage rest. }\end{array}$ & $\begin{array}{l}\text { Post-operative experiences shared between surgeon and dog } \\
\text { owners (see vets section for full report). } 96 \% \text { success rate at } \\
\text { Astonlee. (See vets section for full report). }\end{array}$ \\
\hline $\begin{array}{l}\text { Stiffness with arthritis } \\
\text { Rehabilitation services }\end{array}$ & $\begin{array}{l}\text { Some is inevitable with any technique because of natural } \\
\text { ageing, but we find after graft surgery, if arthritis happens, this } \\
\text { is manageable with medication and rehab services where } \\
\text { needed }\end{array}$ & $\begin{array}{l}\text { Long term benefits of restoring limb function and stability } \\
\text { have been observed (see vets section for results of long term } \\
\text { follow up). }\end{array}$ \\
\hline $\begin{array}{l}\text { Surgical invasiveness: wanting to solve the problem but refer } \\
\text { to the first principle of surgery which is 'First do no harm'. }\end{array}$ & $\begin{array}{l}\text { Replacing the torn ligament is a lot less invasive than bone } \\
\text { sawing techniques, and more effective and with wider } \\
\text { application to different breeds and bodyweights of dog than } \\
\text { lateral suture technique }\end{array}$ & $\begin{array}{l}\text { There are few or no people (surgeons, academics, dog owners) } \\
\text { who would argue against the statement 'techniques that aim to } \\
\text { replace the ligament are less invasive than sawing the bones.' }\end{array}$ \\
\hline Infection control for the surgical procedure & $\begin{array}{l}\text { RCVS Hospital Standard at Astonlee, rigorous protocols in } \\
\text { place. }\end{array}$ & $\begin{array}{l}\text { Very few post op infection problems in } 30 \text { years in many types } \\
\text { of surgery at Astonlee }\end{array}$ \\
\hline Understandable explanation & Replacing the torn ligament with a new one & $\begin{array}{l}\text { Technical challenges such as choice of graft, thickness of } \\
\text { graft, location of drill to position the new graft, clinical } \\
\text { outcomes from graft replacement, have been explored over } 30 \\
\text { years working with the technique. Transplantation medicine } \\
\text { is a modern science. }\end{array}$ \\
\hline Track record & $>30$ years in cruciate surgery & Paatsama (1952), Vaughan (1966), Manning (1979-2016...) \\
\hline Experience of surgeon & $>35$ years & \\
\hline
\end{tabular}

Table 6. Complications

\begin{tabular}{|l|l|l|}
\hline Complications & $\begin{array}{l}\text { Small risk of infection, } \\
\text { failure of graft through } \\
\text { tearing or failure of } \\
\text { anchorage. }\end{array}$ & 30 years' experience \\
\hline Complication rates & $<0.5 \%$ & 30 years' experience \\
\hline Longevity & $\begin{array}{l}\text { Follow ups have been }>10 \\
\text { years }\end{array}$ & 30 years' experience \\
\hline $\begin{array}{l}\text { Would not want to subject } \\
\text { their dog to an operation } \\
\text { they would not want for } \\
\text { themselves }\end{array}$ & & $\begin{array}{l}\text { This is very commonly } \\
\text { stated by dog owners } \\
\text { coming to Astonlee }\end{array}$ \\
\hline
\end{tabular}

Table 7. HRQL (Health Related Quality of Life) instrument

Very important question with a high weighting in the evaluation of the clinical outcome Success and complication rates of different surgical techniques?

Explore the client evaluation of the outcome

Ability of the dog to walk and bear weight on the leg before surgery and after the recovery?

Share the practice procedures for infection control with the client.

Table 8. The table below illustrates some of the critically important aspects, but there are many more that have been demonstrated in this paper.

\begin{tabular}{|l|l|l|}
\hline Risks and hypotheses & Clinical effectiveness & Cost effectiveness \\
\hline Complications & Improvement? & Best evidence \\
\hline $\begin{array}{l}\text { Needing same op on } \\
\text { opposite leg }\end{array}$ & $\begin{array}{l}\text { Clinical performance. } \\
\text { Arthritis. }\end{array}$ & $\begin{array}{l}\text { Solution already available } \\
\text { (?) }\end{array}$ \\
\hline $\begin{array}{l}\text { Hypothesis: change } \\
\text { technique. Peer review vs } \\
\text { raw data. }\end{array}$ & $\begin{array}{l}\text { Profit of GP, specialist } \\
\text { practice? Reduce cost to } \\
\text { clients by } 50 \%\end{array}$ & $\begin{array}{l}\text { C \$1.5billion pa to } \$ 0.75 \\
\text { billion pa in USA? }\end{array}$ \\
\hline
\end{tabular}

In this paper, the questions involved in the hypothesis 'There is a logical analysis of data that can be collected and used to improve surgical outcomes from cruciate ligament surgery to achieve a high level of success' have been seriously considered.

The table 8 below illustrates some of the critically important aspects, but there are many more that have been demonstrated in this paper:

Evidence showing TPLO vs skin graft $=0$.

Graft complication rate dog and man 2\% fail, $0.5 \%$ infection. (Manning and NHS).
There are several different types of evidence that have been explored to answer the complex and multifaceted components to the question:

Types of evidence. Stakeholders.

\section{Qualitative survey}

IKDC includes surgeon and patient reports

Client/patient opinions/feedback

Surgeons' opinions and developmental work

\section{Anatomy, physiology and surgical technique}

Picture of the graft in $\operatorname{dog} 8$ years after it was inserted. (Ligamentisation) (Figure 1).

Quantitative and the debate about 'best practice in research'.

The classical pyramid of the hierarchy of evidence is an aspiration rather than a reality for most of veterinary medicine and surgery because it is rare that studies ever achieve what this hierarchy refers to as the highest standard of evidence.

Variation within what is being measured is more widely appreciated in medicine than veterinary; eg: IKDC.

Limitations of force plate also include cost, availability.

'What type of scientist-practitioner are you?' (Lane and Corrie [34]. This is good question because it opens up the inner debate which is personal to each individual practitioner addressing how they actually do 'clinical reasoning.'

\section{Empiricism and falsification.}

'There is no such thing as objectivity, and all 'truth' is really someone's version based on their background and paradigms.' This leads to theories of social constructivism.

Qualitative analysis explores the richness of data. Quantitative analysis explores specific aspects and applies numbers to them, but in surgery there are a lot of variables. 
Table 9. Pressures on delivering the original research.

\begin{tabular}{|c|c|c|}
\hline Pressure & Reasons & Potential solutions \\
\hline Time & Many pressures on time in a typical veterinary practice & $\begin{array}{l}\text { Challenges to allocating time to a research project when many } \\
\text { other priorities can take precedence }\end{array}$ \\
\hline Cost & Time is a cost & \\
\hline Research planning & $\begin{array}{l}\text { Priorities and planning can be limited by interest, questions } \\
\text { and processes being different for the practitioner compared } \\
\text { to the academic, skill levels and support networks can be } \\
\text { limiting }\end{array}$ & \\
\hline Relevance to the practice & $\begin{array}{l}\text { Very important to look at what really matters to the practitioner } \\
\text { who is in the front line of patient care }\end{array}$ & $\begin{array}{l}\text { It is no good answering a question because it is easy when the } \\
\text { real question the practitioner is faced with requires a different } \\
\text { and more complex approach }\end{array}$ \\
\hline Data collection & $\begin{array}{l}\text { Computer records, written records, interviews and } \\
\text { consultations with clients }\end{array}$ & $\begin{array}{l}\text { Systematic case recording, standardised reporting and use of } \\
\text { computers for archiving are valuable research tools. }\end{array}$ \\
\hline Resources & $\begin{array}{l}\text { The practitioner researcher has to make a living from } \\
\text { satisfying the animal owning public, so time and money for } \\
\text { research is a precious resource. } \\
\text { There is very little sponsorship for in practice research so it } \\
\text { has to be chosen wisely by the clinician researcher as being of } \\
\text { value to their work. }\end{array}$ & $\begin{array}{l}\text { Time can be saved by studying the research plan before } \\
\text { undertaking it, but with the development of surgical technique } \\
\text { often comes the clinical decision making over time as lessons } \\
\text { are learned which can change the course of the research and } \\
\text { the questions being asked and answered. } \\
\text { The rigour of making the choice of what to research without } \\
\text { any resources other than self-funding is also an advantage in } \\
\text { that this serves to really focus the mind on what is important } \\
\text { and practically useful. }\end{array}$ \\
\hline Ethics & $\begin{array}{l}\text { Avoidance of experimentation and even double-blind trials } \\
\text { when best practice is being questioned }\end{array}$ & $\begin{array}{l}\text { Difficult for the practitioner to choose to test two different } \\
\text { treatments when one is strongly believed by the vet and the } \\
\text { client to be the best one }\end{array}$ \\
\hline Client confidentiality & $\begin{array}{l}\text { This needs to be addressed, but is not much of a difficulty } \\
\text { except in following cases where they need to be identified. }\end{array}$ & $\begin{array}{l}\text { Clinical cases can be given numbers or other references to } \\
\text { anonymise them. }\end{array}$ \\
\hline Bias & $\begin{array}{l}\text { There can be bias from having only one surgeon being } \\
\text { involved in the clinical evaluation, but the advantage of one } \\
\text { surgeon applying the same technique is also an advantage } \\
\text { which avoids variation between different surgeons. }\end{array}$ & $\begin{array}{l}\text { Surgery involves many different variables simultaneously. } \\
\text { Care is needed to keep the observations as objective as } \\
\text { possible. }\end{array}$ \\
\hline Sharing of data & $\begin{array}{l}\text { Limitations of available repositories for data submission, } \\
\text { archiving and comparisons in the veterinary world. } \\
\text { Personal results may be closely guarded both for the reason of } \\
\text { wanting to protect the surgeon from being criticised, but also } \\
\text { if the technique is highly successful from the point of view } \\
\text { that other surgeons may choose to practice it and take work } \\
\text { and money away from the originator. } \\
\text { Why would the practitioner surgeon want to do a simpler } \\
\text { technique which earns less money than a more complicated } \\
\text { procedure? }\end{array}$ & $\begin{array}{l}\text { Knee registries in the human field have been widely used and } \\
\text { developed. A cruciate surgery registry could be launched in } \\
\text { the veterinary field. } \\
\text { Sharing of data and expertise can develop referral business } \\
\text { within the originator's practice, and it can have a wider benefit } \\
\text { to the whole profession and the patients and clients we serve. } \\
\text { If the simpler technique has a higher success rate with fewer } \\
\text { and less challenging complications, it can be more satisfying } \\
\text { and less worrying for both the surgeon and the client, and } \\
\text { patient care. Less complications with a less complicated } \\
\text { technique offering consistent results is less time consuming } \\
\text { both during the surgical operation and in the period of aftercare } \\
\text { and any remedial work needed to correct complications. }\end{array}$ \\
\hline $\begin{array}{l}\text { Using a novel technique or old technique that is currently not } \\
\text { favoured by the 'majority view' of peers. }\end{array}$ & $\begin{array}{l}\text { Experience using a technique is one of the important } \\
\text { points why a client chooses a surgeon and their technique. } \\
\text { Introducing a new and novel technique for which there are no } \\
\text { previous clinical experiences on which to draw is a brave step. }\end{array}$ & $\begin{array}{l}\text { Experience in an old technique that was previously } \\
\text { fashionable can provide opportunities for senior surgeons to } \\
\text { utilise their skills. }\end{array}$ \\
\hline Challenge from academics and 'specialists'. & There is pressure to conform to 'expert opinion'. & $\begin{array}{l}\text { Developing an evidence base and a track record is the answer. } \\
\text { Developing an evidence base that is widely accepted as } \\
\text { believable is a better solution. }\end{array}$ \\
\hline
\end{tabular}

Prankel et al. [16] 'These (biomechanical) techniques will not be able to replace careful clinical observation but can be a useful aide to decision making and can detect changes previously inaccessible to the veterinarian.'

Technical issues involved in developing and refining the surgical technique., and comparisons with the technique in human surgery.

Drilling the bone tunnels accurately so they are located at the origin and insertion of the cranial cruciate ligament for the insertion of the replacement graft. In human surgery, the technique is to drill from one entrance point for the drill in the tibia, and this has resulted in the femoral tunnel being located too far cranially in some cases which has been found to be a cause of some complications or failures. In the technique used in the dog, the author surgeon uses two separate entrance locations for the drill bit, starting on the distal lateral femur to arrive at the origin of the cranial cruciate ligament, and then entering via the open stifle joint into the location of the insertion of the ligament through to the medial aspect of the tibia.

The choice of size of hole varies between different dogs and breeds because there are several variables to consider. The size of dog is important because the holes need to be appropriate so they are not too large so as to weaken the bone in a small dog, and not too small in a large dog so the thickness of the graft required is not too restricted.

The thickness of the graft varies with a larger size being used in the larger dogs. The actual thickness of the skin is smaller in smaller dogs.

The anchorage of the graft is achieved by matching the thickness of the graft fairly closely to the bone tunnels so that the bone can lock around the graft, and PDS sutures holding the graft to the muscle and connective tissue. In human surgery, dissolvable screws are used to 


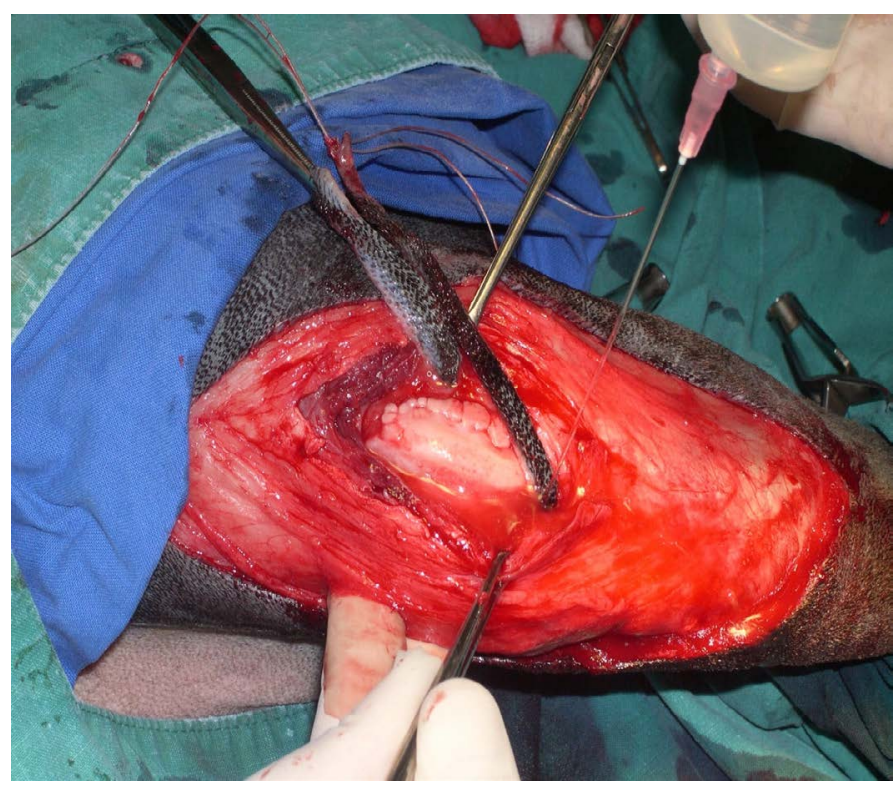

Figure 2. The questions vets and clients ask are often different, but they all matter

lock the graft into the femoral tunnel from the articular side, and there is a large amount of literature reporting technical points on anchorage.

Ligamentisation is recognised in human surgery and widely reported [35], whereas in veterinary surgery there is very little published on the subject together with a large amount of scepticism that is actually can take place. The photograph of the histological picture of a Labrador aged 15 at euthanasia after the skin graft had been placed at age 8 years provides at least some evidence that it can take place. (See above photograph). An important observation on this photograph is that the graft has nuclei in its structure which indicates this is not original collagen and the tissue was viable. It also illustrates that there is no fur growth and no infection which are two often cited reasons why modern day veterinary surgeons question the use of this skin graft technique.

\section{Complications with graft surgery in cruciate ligament replacement in dogs}

\section{Infection}

Rarely seen. Can be seen in gross swelling of the stifle joint with some heat, and some fluid swelling gravitating below the stifle down to the hock.

\section{Preventive measures}

Minimal with good surgical scrubbing technique and theatre hygiene plus good surgical technique and tissue handling.

\section{Graft failure}

Rare to see a sudden change from typically good to excellent progress when the owner typically finds the dog is running off the lead or out of control or trips and there is a sudden onset of lameness in the post op 3-month period. Cranial drawer may represent, but this is sometimes occurring with a simultaneous onset of a click which may be palpable and/or audible. Sometimes this resolves in time over the following 1-2 months, my theory being a meniscal cartilage was dislodged post op but settled down again without tearing the graft. Rarely the graft may tear resulting in a recurrence of the lameness.
Preventive measures ensure the thickness of the skin graft is 'big' for the size of $\operatorname{dog}$ and fits snugly in the 2 drilled bone tunnels to maximise strength of fixing once the sutures have dissolved and the bone tunnels have filled in with new bone. In some cases, the skin is of 'poor quality' in being thin and appearing to lack physical strength, or has become badly soiled by playing in manure on a horse yard, or has some red spots and/or cysts present which can be a concern for the surgeon. Consideration of hygiene of the dog at home before coming for surgery might help by asking owners to keep their dogs away from manure and to wash their dogs once or twice in the week before the operation. Consideration of prevention of post op infections might include the assessment of the skin in the week before the operation, and prescribe antibiotics and antibacterial shampoos before the operation is carried out.

Further research different breeds of dog and different types of dog within the same breed have different skin histology with differences in thickness, strength, and variations depending on hormone status/ presence of Cushing's disease for example. I have successfully operated on a stabilised Cushing's dog with no complications. Further study into the type of skin structures would be helpful but has proved difficult to fund and find wider interest in due to lack of interest in the whole veterinary profession in this surgical procedure. A limited size investigation with the help of Dermatologist David Shearer found little could be distinguished on histology, but the use of an electron microscope might help to discover differences in properties of skin between different dogs and breeds.

Human surgeons use dissolvable screws for fixation of the graft which might be a useful addition to the surgical protocol if any could be made suitable and accessible within the stifle joint of the dog.

\section{Swellings}

These can be:

1) Cysts in the skin graft which are usually of no consequence and occur in the pieces of graft external to the stifle joint but under the skin. Rarely these are removed and sometimes contain sebaceous material which may be brown in colour. These were also recognised and reported by Vaughan (1966).

2) Cysts in the bone of the distal femur have been seen in 2 West Highland Terriers. Both have not resulted in recurrence of lameness, and neither resulted in any recurrence of cranial drawer. They were left alone without any noticeable problems except the owner noticed a swelling.

3) Fluid swelling in and around the stifle plus gravitating down the leg can be due to infection, or can be due to inflammation with no infection which resolves in time.

4) Fluid/pitting oedema not in the stifle but developing in the Achilles tendon area down to and below the hock. This can be associated with a worsening of the lameness but is usually of no consequence and resolves with application of frozen peas and judicious use of NSAID's.

5) Tumours in the bone of the distal femur have been seen in Rottweilers, one being present at the same time the owner actually heard an audible sound when the cranial cruciate ligament snapped. Occasionally bone tumours occur in the distal femur of the Rottweiler so radiographs are particularly important in this breed. There may be no connection between the development of bone tumours and the surgical technique. 


\section{Preventive measures}

Hygiene to prevent infection is important, but most swellings seen are not due to infection. Some swelling can be avoided by attention to ligation of arterioles, and some dogs have very inflamed joints which have large amounts of vascularisation which can lead to post op swelling. Usually the swelling occurs in the first 2-3 weeks of the recovery period, but occasionally swelling even pitting oedema of the Achilles area can occur 1 month after the operation when the preceding 4 weeks showed no presence of swelling at all. Strict adherence to the instruction 'lead exercise only and no stairs of jumping' is critically important and not always easy to achieve owner or patient compliance.

\section{Check lists}

Airline pilots have been helping surgeons to appreciate the importance of checklists. The airline industry realised some years ago that checklists save lives and so they have rigorous systems in place to try to prevent a disaster such as the apparent running out of fuel in the recent Brazilian air crash (November 2016). They cannot prevent everything from happening but they focus on it, and surgeons have done the same now to minimise 'non-events' which they refer to as 'events which should never happen but sometimes do. The development of checklists can help in the development of surgical technique because each check needs to have a reason behind it, and that requires reflective practice; i.e. something is learned from each critical incident or 'stroke of the scalpel.'

Further research: Is there a possible relationship between the presence of a graft in the distal femur and the development of a bone tumour?

\section{Challenges to asking the right questions. (for vets and clients)}

The question for me as a veterinary surgeon with a lifetime commitment to my profession is 'what is best for my patients?' Dog owning clients have the same question. There are technical questions as well as questions about the recovery from surgery and the ability of the patient to resume the activities enjoyed before the intervention. It is clear from history, study of the literature, personal experience of attending conferences for the past 35 years, and my own clinical experience that veterinary surgeons have been led by fashion rather than evidence. The late Professor Vaughan confirmed to me in writing before he died that he had been perfectly happy with using the old graft technique and the only reason he changed was fashion.

Clients often follow their veterinary surgeons' advice and assume it is given with a reliable evidence base. However, many clients have been challenging their veterinary surgeons to deliver the evidence that informs their decision to recommend a particular type of cruciate surgery for their dog. When that has not been forthcoming or they find it unconvincing they may choose to self-refer themselves to a place where their questions have been answered to their satisfaction. Many clients are very discerning and justifiably demanding of their veterinary surgeons in helping to make their decision for their dog who they care about very much, but they also feel they have a moral obligation to consider this carefully. Clients want to feel they have done the right thing for their dog, so they want to know what the right questions are to ask.

Many vets decide to align themselves with what is considered to be 'best practice' by the majority and what they feel is going to support them in the literature. With the removal of the old graft techniques from regular practice, there are many veterinary surgeons who feel uncomfortable about recommending or supporting or doing the old graft techniques themselves, even though many (over 50 years old) have actually practised this in the past with success (Table 9).

\section{Special place of practitioner research}

Practitioners can have a career lifetime of continuous experience and working knowledge of clinical cases following patients for the whole of their lifetime in a special relationship with their clients. The author/practitioner/surgeon has been in the same practice he founded in 1986 continuously to the time of writing (2016).

Practitioners most value papers by practitioners [36].

'Effective communication between doctor and patient is a central clinical function that cannot be delegated [37].

Svarstad [12] There was a change in thinking from 'Follow Doctor's orders' to 'Maybe it's the Doctors who have got the problem of patients not following instructions?'

Repeatability of surgeons' results. NNT. (Number needed to treat before encountering a problem is a recent more popular method of looking at outcomes).

Each primary care consultation is an exceptional opportunity [30].

'Meetings between experts'. Sharing medical information [38].

Consultation skills are important in veterinary practice [27].

Reflection is an essential consultation skill [39].

A dog lover shares exacting standards when judging their dog's ability to exercise.

\section{Managing clinical work.}

Evaluation of technique in experienced and less experienced surgeons is important in the management of the clinical function of the practice, whether that be a general practice, veterinary hospital or a referral establishment. In human surgery, there is a realisation that complications cost a lot of time and money, as well as causing sometimes horrifying consequences for the patient. All of the considerations of different types of evidence are important in the delivery of care through surgery.

\section{Methods and materials}

\section{Literature searches}

Clinical studies by the author at Astonlee Veterinary Hospital, surgery and case follow ups over 30 years.

Over 30 years of asking clients 'what questions do you have that you would like me to answer in helping you to make your decision about the choice of intervention available to you for your dog with the ruptured cruciate ligament?'

\section{FAQ's by clients (see www.astonlee.co.uk).}

Survey in The Veterinary Times using a series of articles introducing the topic. This included a questionnaire to obtain the opinions of the veterinary surgeon, veterinary nurse and some other readers of the widely distributed publication.

\section{Competing interests}

The only competing interests which the author perceives as being in conflict with this paper are the numbers of veterinary surgeons who 
have their own vested interests in making their particular choices of cruciate surgery for their patients which are rarely the technique the author uses. On the other hand, many dog owners choose the technique the author advocates and practices.

The author owns and runs his own Veterinary Hospital.

\section{Declaration}

1. I hereby warrant that I have obtained permission from the copyright holder to reproduce in the Article (in all media including print and electronic form) material not owned by me, and that I have acknowledged the source.

2. I hereby warrant that this Article contains no violation of any existing copyright or other third party right or any material of an obscene, indecent, libelous or otherwise unlawful nature and that to the best of my knowledge this Article does not infringe the rights of others;

3. I warrant that I have not assigned or licensed any rights in the Article and no previous version of the Article has been published anywhere in the world.

4. I hereby warrant that in the case of a multi-authored Article I have obtained, in writing, authorization to enter into this Agreement on their behalf and that all co-authors have read and agreed the terms of this Agreement;

5. I warrant that any formula or dosage given is accurate and will not if properly followed injure any person or animal.

6. I will indemnify and keep indemnified the Editors, RCVS Knowledge and Veterinary Evidence against all claims and expenses (including legal costs and expenses) arising from any breach of this warranty and the other warranties on my behalf in this Agreement.

\section{References}

1. Conzemius MG, Evans RB, Besancon MF, Gordon WJ, Horstman CL, et al. (2005) Effect of surgical technique on limb function after surgery for rupture of the cranial cruciate ligament in dogs. $J$ Am Vet Med Assoc 226: 232-236

2. Lazar TP, Berry CR, deHaan JJ, Peck JN, Correa M (2005) Long-term radiographic comparison of tibial plateau levelling osteotomy versus extracapsular stabilization for cranial cruciate ligament rupture in the dog. Vet Surg. 34: 133-41.

3. Ficek K, Wieczorek J, Stodolak E, Kajor M, Kosenyuk Y (2012) A revised surgical concept of anterior cruciate ligament replacement in a rabbit model: preliminary investigations. Journal of Tissue Engineering and Regenerative Medicine, suppl. SUPPL. 1 6: 50

4. Ye L, Zhang P, Duval S, Su L, Xiong Q, et al. (2013) Thymosin $\hat{I}^{2} 4$ increases the potency of transplanted mesenchymal stem cells for myocardial repair. Circulation 128: S32-41. [Crossref]

5. Markatos K, Kaseta MK, Lallos SN, Korres DS, Efstathopoulos N (2013) The anatomy of the ACL and its importance in ACL reconstruction. European journal of orthopaedic surgery \& traumatology: orthope' die traumatologie 23: 747-752.

6. Pauzenberger L, Syré S, Schurz M (2013) "Ligamentization" in hamstring tendon grafts after anterior cruciate ligament reconstruction: a systematic review of the literature and a glimpse into the future. Arthroscopy 29: 1712-1721. [Crossref]

7. Lars-Petter G, Roald B, Kjersti S, Ove F, Lars E (2008) Development of a national cruciate ligament surgery registry: The Norwegian National Knee Ligament Registry. Am J Sports Med 36: 308-315. [Crossref]

8. Boyer P, Villain B, Pelissier A, Loriaut P, Dallaudière B, et al. (2014) Current state of anterior cruciate ligament registers. Orthop Traumatol Surg Res 100: 879-883.

9. Fox SP (2014) pain management in small animal medicine. (HRQOL). CRC Press

10. Appleby J, Poteliakhoff E, Shah K, Devlin N (2013) Using patient reported outcome measures to estimate cost-effectiveness of hip replacements in English hospitals. JRSM 106: $323-331$.
11. Priddy NH, Tomlinson JL, Dodam JR, Hornbostel JE (2003) Complications with and owner assessment of the outcome of tibial plateau levelling osteotomy for treatment of cranial cruciate ligament rupture in dogs :193 cases (1997-2001). JAVMA 222: 17261732.

12. Svarstad BL, (1974) 'The doctor-patient encounter: an observational study of communication and outcome.' PhD thesis. University of Wisconsin.

13. Brown DC (2007) Outcomes based medicine in veterinary surgery: getting hard measures of subjective outcomes. Vet Surg 36: 289-292. [Crossref]

14. Brown DC (2014) The Canine Orthopaedic Index. Vet Surg 43: 232-254.

15. Hospodar SJ, Miller MD (2009) Controversies in ACL reconstruction: bone-patellar tendon-bone anterior cruciate ligament reconstruction remains the gold standard. Sports Med Arthrosc 17: 242-246. [Crossref]

16. Prankel S, Corbett M, Bevins J, Davies J (2016) Biomechanical analysis in veterinary practice. In Practice 38: 176-187

17. Rawlins MD, (2015) National Institute for Clinical Excellence: NICE works. JRSM 108: 213-219.

18. Vaughan LC, Bowden NLR (1966) The use of skin for the replacement of the anterior cruciate ligament in the dog: A review of 30 cases. J Small Anim Prac 5: 167-171

19. Wiseman-Orr ML, Nolan AM, Reid J, Scott EM (2004) Development of a questionnaire to measure the effects of chronic pain on health-related quality of life in dogs. Am J Vet Res 65: 1077-1084. [Crossref]

20. Manning PR (2006) Consultation skills in veterinary practice. DProf thesis Middlesex University, UK.

21. Manning PR (2011) Evaluating clinical outcomes: chance to express views on cruciate issues. Veterinary Times 20: 28-29. Manning PR (2011) Evaluating cruciate surgery. Vet Times 18: 13 .

22. Paatsama S (1952) Ligament Injuries in the Canine Stifle joint. MSc thesis, Helsinki University, Finland. Preserved at the RCVS Library.

23. Wiseman-Orr ML, Scott MS, Reid J, Nolan AM (2006) Validation of a structured questionnaire as an instrument to measure chronic pain in dogs on the basis of effects on health-related quality of life. AJVT 67: 1826-1836.

24. Gutacker N, et al (2015) Should English healthcare providers be penalised for failing to collect patient-reported outcome measures? A retrospective analysis. JRSM 108: $304-$ 316.

25. Innes JF, Barr ARS (1998) Can owners assess outcome following treatment of canine cruciate ligament deficiency? JSAP 39: 373-378.

26. Hefti F, Müller W, Jakob RP, Stäubli HU (1993) Evaluation of knee ligament injuries with the IKDC form. Knee Surg Sports Traumatol Arthrosc 1: 226-234. [Crossref]

27. Manning PR (2003) The successful repair of rupture of the cranial cruciate ligamen in the dog using a skin prosthesis. BSAVA Congress 2003 Scientific Proceedings page 596.

28. Manning PR. (2004) 'The semi-structured interview', Veterinary Review November 57-59.

29. Robbe R, Paletta GA (2004) Soft-Tissue graft fixation in anterior cruciate ligament reconstruction. Op Tech Sp Med 12: 188-194.

30. Stott NC, Davis RH (1979) The exceptional potential in each primary care consultation. $J$ R Coll Gen Pract 29: 201-205. [Crossref]

31. Lind M, Menhert F, Pedersen AB (2009) The first results from the Danish ACL reconstruction registry: Epidemiologic and 2year follow-up results from 5,818 knee ligament reconstructions. Knee Surg Sports Traumatol Arthrosc 17: 117-124. [Crossref]

32. Granan LP, Bahr R, Steindal K, Furnes O, Engebretsen L (2008) Development of a national cruciate ligament surgery registry: the Norwegian National Knee Ligament Registry. Am J Sports Med 36: 308-315. [Crossref]

33. Irrgang JJ, Anderson AF, Boland AL et al (2001) Development and validation of the International Knee Documentation Committee Subjective Knee form. Am J Sports Med 29: 600-613.

34. Lars E, Magnus F, Martin L (2015) Why registries analysing cruciate ligament surgery are important. Br J Sports Med 49: 636-638.

35. Ziliak ST, McCloskey DN (2012) The cult of statistical significance. How the standard error costs us jobs, justice and lives. University of Michigan Press. 
Paul RM (2017) The cruciate question: what are the right questions to ask when evaluating clinical outcomes from cruciate ligament surgery in the dog?

36. Duncanson, Graham R, (2007) An investigation of the difficulties faced by practitioner researchers in publication. DProf thesis, Middlesex University.

37. Stewart MA (1995) Effective physician-patient communication and health outcomes: a review. CMAJ 152: 1423-1433. [Crossref]
38. Tuckett D, Boulton M, Olson C (1985) Meetings between Experts: an approach to sharing ideas in medical consultations. Tavistock, London.

39. Adams CL, Nestel D, Wolf P (2006) Reflection: a critical proficiency essential to the effective development of a high competence in communication. J Vet Med Educ 33: 58-64. [Crossref]

Copyright: (C2017 Paul RM. This is an open-access article distributed under the terms of the Creative Commons Attribution License, which permits unrestricted use, distribution, and reproduction in any medium, provided the original author and source are credited. 